\title{
PENERAPAN MODEL PEMBELAJARAN EXAMPLE NON EXAMPLE UNTUK MENINGKATKAN HASIL BELAJAR SISWA PADA POKOK BAHASAN DINAMIKA HIDROSFER KELAS X SMA NEGERI 10 KOTA TERNATE
}

\author{
Eva Marthinu ${ }^{1}$, Rusdin Nurdin ${ }^{2}$ \\ 1 Staf Pengajar Program Studi Pendidikan Geografi, FKIP-UNKHAIR \\ 2 Mahasiswa Program Studi Pendidikan Geografi, FKIP-UNKHAIR
}

Author Correspondence: evamarthinu@gmail.com

$\begin{array}{ll}\text { Diterima } & : 09-09-2019 \\ \text { Direvisi } & : 10-10-2019 \\ \text { Dipublikasi } & : 01-11-2019\end{array}$

\begin{abstract}
Abstrak. Penelitian ini dilakukan dengan tujuan untuk meningkatkan hasil belajar siswa kelas X SMA Negeri 10 Kota Ternate. Pada pokok bahasan Dinamika Hidrosfer melalui penerapan model pembelajaran Example Non Example dengan menggunakan lembara kerja (kuisioner) adapun teknik analisis data yang di gunakan adalah Observasi, dan angket. Untuk meningkatkan hasil belajar siswa. Jenis penelitian yang digunakan adalah penelitian deskripti kualitatif Dengan mengacu pada model pembelajaran Example Non Example. Untuk meningkatkan hasil belajar siswa. Tempat penelitian adalah SMA Negeri 10 Kota Ternate. Ketuntasan hasil belajat siswa secara keseluruhan dapat dilihat pada siklus I sebanyak 33 orang yang belum tuntas atau sebanyak 8\%. Yang belum mencapai ketuntasan belajar atau belum mencapai kkm. Sedangkan pada siklus II sudah mengalami peningkatan hasil belajar siswa sebanyak 32 orang yang tuntas atau sebanyak $89 \%$ siswa yang mencapai ketuntasan belajar, sehingga dapat dikatakan bahwa pada siklus II siswa dapat dikatakan telah berhasil atau mencapai KKM.
\end{abstract}

Kata kunci: hasil belajar, example non example, model pembelajaran, dinamika hidrosfer

\section{PENDAHULUAN}

Pendidikan merupakan usaha untuk membantu perkembangan potensi dan kemampuan anak agar bermanfaat bagi kepentingan hidupnya sebagai seorang individu dan sebagai anggoya masyarakat atau warga Negara. Pendidikan dapat terlaksana dengan baik apabila terdapat keterkaitan yang didaktis dan pendagogis dari seluruh komponen pendidikan baik sarana maupun prasarana (Rustam Hasim, Subhan Hayun, 2018).

Model pembelajaran merupakan cara atau bagaimana peserta didik dapat berfikir terhadap permasalahan yang ada di sekitarnya melalui analisis contoh berupa gambar-gambar/foto/ kasus yang bermuatan masalah. Siswa diarahkan untuk mengidentifikasi masalah, mencari alternatif pemecahan masalah, dan menentukan cara pemecahan masalah yang paling efektif, serta melakukan tindak lanjut (Komalasari, (2010). Berkaitan dengan pernyataan tersebut Dalyono, (2007) mengatakan bahwa seorang peserta didik yang ingin mencapai cita-citanya tentu harus belajar dengan giat. Bukan hanya di sekolah saja, tetapi juga harus belajar di rumah, masyarakat, lembaga pendidikan ekstra di luar sekolah, berupa kursus, les privat, bimbingan studi, dan sebagainya.

Aktivitas dalam kegiatan belajar tidak lain adalah untuk mengkonstruksi pengetahuan peserta didik. peserta didik aktif membangun pemahaman atas persoalan atau segala sesuatu yang peserta didik hadapi dalam kegiatan pembelajaran. Aktivitas belajar peserta didik merupakan unsur dasar yang penting bagi keberhasilan proses pembelajaran. Melalui aktivitas, seorang peserta didik akan dapat memahami pelajaran dari pengalamannya sehingga akan mempertinggi hasil belajarnya. Aktivitas yang dilakukan oleh peserta didik dalam proses pembelajaran merupakan salah satu faktor penting yang sangat mempengaruhi hasil belajar peserta didik. Menurut Hermawan (2007), belajar merupakan hak setiap individu, dan dengan belajar setiap individu akan mendapatkan pengetahuan dan wawasan yang lebih 
Eva Marthinu dan Rusdin Nurdin. 2019. hasil belajar, example non example, model pembelajaran, dinamika hidrosfer

luas dari sebelumnya serta mampu mengkonstruk sendiri pengetahuan, informasi dan pengalaman baik yang didapat maupun yang dialami dan dipengaruhi oleh lingkungan. Menurut Slameto dalam Handayani (2010), belajar merupakan suatu proses usaha yang dilakukan untuk memperoleh suatu perubahan tingkah laku yang baru secara keseluruhan, sebagai hasil pengalamanya sendiri dalam interaksinya dengan lingkungannya.

Menurut Witherington yang dikutip dan diterjemahkan oleh Sukmadinata dalam Handayani (2010), belajar merupakan perubahan dalam kepribadian, yang diartikan sebagai pola-pola respon yang baru, yang berbentuk keterampilan, sikap, kebiasaan, pengetahuan dan kecakapan. Faktor-faktor yang mempengaruhi belajar Menurut Soemanto dalam Setyowati (2007), dalam belajar, banyak sekali faktor yang mempengaruhi belajar namun dari sekian banyaknya faktor yang mempengaruhi belajar, hanya dapat digolongkan menjadi tiga macam yaitu: (1) Faktor-faktor stimuli belajar Stimuli belajar adalah segala hal di luar individu yang merangsang individu itu untuk mengadakan reaksi atau pembuatan belajar, misalnya panjangnya bahan pelajaran, kesulitan bahan pelajaran, berartinya bahan pelajaran, berat ringannya tugas, suasana lingkungan eksternal; (2) Faktor-faktor metode belajar Metode mengajar yang dipakai oleh guru sangat mempengaruhi metode belajar yang dipakai oleh si pelajar maka metode yang dipakai oleh guru menimbulkan perbedaan yang berarti bagi proses belajar, misalnya tentang kegiatan berlatih atau praktek, menghafal atau mengingat, pengenalan tentang hasil-hasil belajar, bimbingan dalam belajar; (3) Faktor-faktor individual Faktor-faktor individual juga sangat besar pengaruhnya terhadap belajar seseorang, misalnya tentang kematangan individu, usia, perbedaan jenis kelamin, pengalaman sebelumnya, motivasi, dan kondisi kesehatan.

Belajar merupakan jalan menuju kesuksesan. Dengan belajar, seseorang dapat mengetahui banyak hal. Dalam hal ini, Islam pun amat menekankan tentang belajar. Tujuan belajar dalam Islam bukan mencari rezeki di dunia semata, tetapi untuk sampai kepada hakikat, memperkuat akhlak, artinya mencari atau mencapai ilmu yang sebenarnya dengan akhlak yang sempurna (Tohirin, 2006). Islam mengajarkan umatnya untuk terus belajar selagi masih ada kesempatan dan sebelum jasad bersatu dengan tanah. Islam tidak saja mencukupkan pada anjuran supaya belajar bahkan menghendaki supaya seseorang itu terus melakukan pembahasan, research (penelitian) dan studi. Rasulullah SAW dalam haditsnya menyatakan, "Seseorang itu dapat dianggap seseorang yang alim dan berilmu, selama ia masih terus belajar. Apabila ia menyangka bahwa ia sudah serba tahu, maka sesungguhnya ia jahil (bodoh), menurut" (Dalyono, 2007).

Slameto (1995) menyatakan bahwa "belajar adalah suatu proses usaha yang dilakukan yang baru secara keseluruhan sebagai hasil pengalaman sendiri dalam interaksi dengan lingkungan". Hasil belajar merupakan ukuran keberhasilan seorang siswa setelah mengikuti pelajaran disuatu sekolah dengan mengunakan alat evaluasi berupa test standar. Hasil belajar dapat diartikan pula sebagai indikator kualitas dari pengetahuan yang dimiliki seseorang. Hasil belajar sebagai tingkat keberhasilan siswa mengenai jumlah materi pelajaran yang diserap melalui proses belajar mengajar. Hasil belajar adalah indikator kualitas dari pengetahuan yang dimiliki seseorang. Prestasi disekolah pada umunya dinyatakan dengan nilai-nilai berupa angka-angka. Sudjana (1991) mengemukakan bahwa "hasil belajar adalah menemukan pengalaman belajar", sementara Soewondo (1982) mengemukakan bahwa "hasil belajar adalah tingkat keberhasilan siswa dalam mempelajari materi pelajaran di sekolah yang diberikan oleh guru".

Menurut Rochyandi, Yadi (2004) model pembelajaran Example Non Example adalah tipe pembelajaran yang mengaktifkan siswa dengan cara guru menempelkan contoh gambar-gambar yang sesuai dengan tujuan pembelajaran dan gambar lain yang relevan dengan tujuan pembelajaran, kemudian siswa disuruh untuk menganalisisnya dan mendiskusikan hasil analisisnya sehingga siswa dapat membuat konsep yang esensial. Selanjutnya Chotimah (2007) menjelaskan bahwa examples non examples adalah model pembelajaran yang menggunakan contoh-contoh. Contoh-contoh dapat diperoleh dari kasus atau gambar yang relevan dengan Kompetensi Dasar. Dalam penerapannya, model pembelajaran harus dilakukan sesuai dengan kebutuhan peserta didik karena masing-masing model pembelajaran memiliki 
tujuan, prinsip, dan tekanan utama yang berbeda-beda. Pendapat tersebut menjelaskan bahwa penerapan model pembelajaran perlu memperhatikan kebutuhan siswa dan apa yang dimiliki guru agar pembelajaran dapat berlangsung lebih evektif. Menurut Isjoni, (2009) model example non example merupakan salah satu pendekatan Group investigation dalam pembelajaran kooperatif yang dirancang untuk mempengaruhi pola interaksi peserta didik dan meningkatkan perolehan hasil akademik. Tipe pembelajaran examples non examples dimaksudkan sebagai alternatif terhadap model pembelajaran kelas tradisional dan menghendaki siswa saling membantu dalam kelompok kecil dan lebih dicirikan oleh penghargaan kooperatif dari pada individu" (Muslimin Ibrahim, 2000).

\section{METODE PENELITIAN}

Penelitian ini merupakan penelitian tindakan kelas (PTK), yaitu suatu penelitian berisi tindakantindakan yang bertujuan untuk meningkatkan kualitas belajar siswa dengan menggunakan metode deskripti kualitatif, Penelitian tindakan kelas sebagai rangkaian langka-langka sistematis. Setiap langkah memiliki empat tahap yaitu, perencanaan, (Planning) tindakan, (Acting) pengamatan, (Observing) dan refleksi (Reflecting) (Suwandi: 2010). Artinya dalam melakukan penelitian ini, peneliti bekerja sama dengan guru yang mengajar di kelas X IPS 1 SMA Negeri 10 Kota Ternate. Jadi PTK dimaksudkan untuk mengembangkan keterampilan atau pendekatan deskriptif kualitatif dengan model pembelajaran example non example untuk meningkatkan hasil belajar siswa pada pokok bahasan dinamika hidrosfer.

Penelitian ini dilaksanakan di sekolah SMA Negeri 10 Kota Ternate yang terletak di Jl. Ki Hajar Dewantara No.5 Kel. Takoma Kec. Kota Ternate Tengah. Sekolah tempat penelitian adalah sebagai peneliti guru mata pelajaran geografi, yang dilaksanakan pada semester genap dengan kurun waktu penelitian selama bulan Februari hingga Maret 2019.

Pengumpulan data dalam penelitian ini dilakukan melalui beberapa teknik, yaitu pengamatan, wawancara dan dokumentasi. Dalam pengumpulan data, peneliti berkomunikasi dan berinteraksi dengan subjek peneliti. Dalam pengumpulan data, ketiga metode tersebut tidak dipergunakan secara terpisah satu dengan yang lainnya, melainkan dipergunakan secara bersama. Metode yang satu melengkapi metode yang lain, sesuai dengan situasi dan kondisi yang ada. (Nani I. Rajaloa1, Rustam Hasim, 2018).

\section{HASIL DAN PEMBAHASAN}

Tahap pelaksaan siklus I, merupakan tahap awal pengambilan hasil belajar siswa dengan menggunakan model pembelajaran example non example untuk meningkatkan hasil belajar sisiwa yang diberikan peneliti selama proses belajar mengajar. Hasil yang didapatkan mununjukkan hasil aktivitas siswa masih dikatakan rendah, dikarenakan kurangnya kreasi guru dalam menerapkan model pembelajaran.

\section{Hasil Aktifitas Siswa}

Hasil aktivitas siswa diperoleh selama proses belajar mengajar berlangsung didalam kelas yang diamati oleh peneliti adapun rekapan dari hasil aktivitas siswa pada siklus I dapat dilihat pada tabel dibawah ini.

Tabel 1. Hasil aktivitas siswa siklus I

\begin{tabular}{ccc}
\hline Alternatif Jawaban & F & \% \\
\hline Sangat Baik & - & - \\
Baik & 3 & 8 \\
Cukup & 9 & 25 \\
Rendah & 24 & 67 \\
Gagal & - & - \\
Jumlah & 36 & 100 \\
\hline
\end{tabular}


Berdasarkan tabel diatas menunjukkan bahwa hasil aktifitas siswa dalam mengikuti mata pelajaran geografi belum ada peningkatan, hal ini dapat dilihat dari hasil presentasi di atas bahwa hasil belajar siswa mengikuti mata pelajaran geografi dengan hasil presentasi sangat baik sebanyak $8 \%$, dan siswa yang mencapai nilai cukup sebanyak $25 \%$, sendangkan yang mendapatkan nilai rendah paling banyak yaitu $67 \%$ dari hasil ini bisa disimpulkan bahwa sebagian dari aktivitas belajar siswa belum meningkat.

\section{Hasil Aktivitas Guru}

Hasil aktivitas guru diperoleh selama proses belajar mengajar di dalam kelas adapun hasil rekapan nilai aktivitas guru pada siklus I dapat dilihat pada tabel 2 dibawah ini.

Tabel 2. Hasil aktivitas guru siklus I

\begin{tabular}{ccccc}
\hline $\begin{array}{c}\text { Aspek yang } \\
\text { diamati }\end{array}$ & $\begin{array}{c}\text { Skor } \\
\text { perolehan }\end{array}$ & Skor total & presentasi & Keterangan \\
\hline A1-A15 & 9 & 15 & 60 & Cukup \\
\hline
\end{tabular}

Berdasar tabel 2 diatas menunjukkan hasil aktivitas guru pada siklus I pada saat proses belajar mengajar berlangsung yang diamati observer masih rendah hal ini dilihat dari skor perolehan yang didapat yaitu 9 $(60 \%)$. Berdasarkan dari hasil tes pada siklus I maka dapat dilihat hasil belajar siswa pada siklus I dapat dilihat pada tabel berikut.

\section{Hasil Belajar Siswa}

Berdasarkan dari hasil tes pada siklus I maka dapat dilihat hasil belajar siswa pada siklus I dapat dilihat pada tabel berikut.

Tabel 3. Hasil Belajar Siswa Siklus I

\begin{tabular}{ccc}
\hline Alternatif Jawaban & F & \% \\
\hline Sangat Baik & 1 & 3 \\
Baik & 2 & 6 \\
Cukup & 5 & 14 \\
Rendah & 24 & 67 \\
Gagal & 4 & 11 \\
Jumlah & 36 & 100 \\
\hline
\end{tabular}

Berdasarkan tabel diatas menunjukan bahwa hasil belajar siswa pada pada siklus I dengan penerapan model pembelajaran Example Non Example untuk meningkatkan hasil belajar siswa pada pokok pembahasan dinamika hidrosfer kelas x SMA Negeri 10 Kota Ternate. Hal ini dapat dilihat dari hasil presentasi di atas bahwa hasil belajar siswa pada pokok bahasan dinamika hidrosfer dari 36 siswa yang mengikuti tes hanya $3 \%$ dan $6 \%$ orang siswa yang mencapai kriteria ketuntasan minimal (KKM). Sedangkan yang lainya belum mencapai kkm sebanyak siswa lainya belum tuntas. Sebanyak $14 \%$ siswa yang nilai KKM cukup dan sebanyak $67 \%$ yang nilainya rendah sedangkan siswa yang tidak tuntas atau gagal sebanyak $11 \%$

Hasil aktivitas siswa diperoleh selama proses belajar mengajar berlangsung yang diamati oleh peneliti, di SMA Negeri 10 Kota Ternate. Adapun rekapan aktivitas siswa pada siklus II dapat dilihat pada tabel 4. di bawah ini: 


\section{a.Hasil Aktivitas Siswa Siklus II}

Hasil aktivitas siswa diperoleh selama proses belajar mengajar berlangsung yang diamati oleh peneliti, di SMA Negeri 10 Kota Ternate. Adapun rekapan aktivitas siswa pada siklus II dapat dilihat pada tabel 4. di bawah ini:

Tabel 4. Hasil Aktifitas Sisiwa Siklus II

\begin{tabular}{ccc}
\hline Alternatif Jawaban & F & \% \\
\hline Sangat baik & 22 & 61 \\
Baik & 14 & 39 \\
Cukup & - & - \\
Rendah & - & - \\
Gagal & - & - \\
Jumlah & 36 & 100 \\
\hline
\end{tabular}

Berdasarkan hasil rekapan aktivitas siswa, diatas dapat dikatakan meningkat. Pada siklus II karena peneliti menggunakan metode atau cara mengajar yang berbeda dengan metode example non example untuk meningkatkan hasil aktivitas belajar siswa di SMA Negeri 10 Kota Ternate. sehingga proses belajar mengajar menarik perhatian siswa sehingga membuat siswa aktif dan bersemangat dengan skor perolehan 61 atau 39.

\section{b. Aktifitas Guru Siklus II}

Hasil aktivitas guru diperoleh selama proses belajar mengajar berlangsung adapun rekapan aktifiras guru pada siklus II dapat kita lihat pada tabel 5. dibawah ini.

Tabel 5. Hasil Aktivitas Guru Siklus II

\begin{tabular}{ccccc}
\hline $\begin{array}{c}\text { Aspek yang di } \\
\text { amati }\end{array}$ & $\begin{array}{c}\text { Skor } \\
\text { perolehan }\end{array}$ & Skor total & Presentase & Keterangan \\
\hline A1-A15 & 14 & 15 & 93,33 & Sangat baik \\
\hline
\end{tabular}

Dari hasil presentasi diatas menunjukkan bahwa hasil aktivitas guru pada siklus II pada saat proses belajar mengajar berlangsung sudah sangat baik dilihat dari skor perolehan sebanyak 14 atau 93,33\%. Ini disebabkan guru sudah melakukan persiapan dengan baik dan lebih memotivasi siswa selama proses belajar mengajar berlangsung.

\section{c. Hasil Belajar Siswa siklus II}

Berdasarkan hasil tes siklus II maka dapat dilihat hasil belajar siswa siklus II Tabel 6. dibawah ini.

Tabel 6. Hasil Belajar Siswa Siklus II

\begin{tabular}{ccc}
\hline Alternatif Jawaban & F & \% \\
\hline Sangat Baik & 13 & 36 \\
Baik & 17 & 47 \\
Cukup & 3 & 8 \\
Rendah & & 0 \\
Gagal & & 0 \\
Jumlah & 36 & 100 \\
\hline
\end{tabular}


Berdasarkan tabel diatas menunjukan bahwa hasil belajar siswa pada pada siklus II dengan penerapan model pembelajaran Example Non Example untuk meningkatkan hasil belajar siswa pada pokok pembahasan dinamika hidrosfer kelas x SMA Negeri 10 Kota Ternate. Sudah meningkat, hal ini dapat dilihat dari hasil presentasi di atas bahwa hasil belajar siswa pada pokok bahasan dinamika hidrosfer yang dimana dari 36 siswa yang mengikuti tes sebanyak 36\% sangat baik $47 \%$ baik $8 \%$ cukup, hasil belajar siswa yang mencapai kriteria ketuntasan minimal KKM. Karena guru sudah mampu menciptakan suasan yang lebih baik dan efektif serta siswa sudah tidak terlihat kaku dengan model yang digunakan oleh guru.

\section{a.Aktifitas Siswa}

Data siswa diperoleh dalam proses belajar mengajar berlangsung dengan menggunakan metode example non example dimana pada siklus I aktivitas siswa masih kurang dan pada siklus II aktivitas siswa mengalami peningkatan, hal ini dapat di katakan bahwa aktifitas siswa pada siklus II mengalami peningkatan dikarenakan model yang diterapkan peneliti sudah dapat dipahami oleh siswa sehingga membuat siswa lebih aktif dan bersemangat. Adapun peningkatan aktivitas belajar siswa pada siklus I dan siklus II dapat dilihat pada gambar 1. berikut ini:

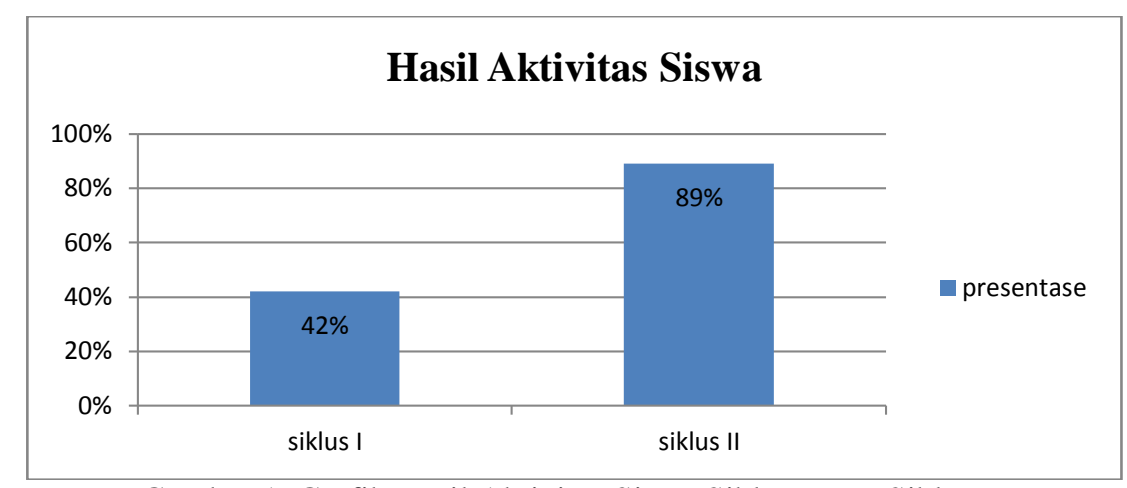

Gambar 1. Grafik Hasil Aktivitas Siswa Siklus I Dan Siklus II

Berdasarkan gambar 1 diatas menunjukkan bahwa adanya perbedaan hasil aktifitas siswa pada siklus I dan II berdasarkan hasil aktivitas siswa dalam proses belajar mengajar pada siklus I dapat dikatakan masih kurang meningkat ini disebabkan belum adanya rasa ketertarikan siswa terhadap pelajaran yang disampaikan oleh guru. Ada sebagian siswa yang belum bisa menyesuaikan diri dengan model pembelajaran example non example yang telah digunakan oleh guru hal ini dapat kita lihat bahwa hasil skor akhir aktivitas belajar siswa pada siklus I sebanyak $42 \%$ atau belum tuntas.

Dengan demikian peneliti mengevaluasi hasil aktivitas siswa, maka peneliti melanjutkan pada siklus II. Hasil aktifitas siswa dalam proses belajar mengajar pada siklus II telah meningkat dan siklus sebelumnya. Dalam proses belajar mengajar siswa sudah menyesuaikan diri dengan penerapan model pembelajaran example non example untuk meningkatkan hasil belajar siswa proses pembelajaran yang berlangsung dikelas siswa sudah banyak dituntut untuk aktivitasnya, siswa sudah mulai menunjukan minat dan perhatian siswa serta siswa aktif untuk bertanya kepada guru tentang dinamika hidrosfer yang belum jelas di jelaskan oleh guru dan mampu memberikan jawaban atas apa yang ditanyakan oleh guru (peneliti). Hal ini dapat dilihat dari hasil aktifitas siswa dari siklus I dengan skor perolehan $42 \%$ meningkat menjadi $89 \%$ pada siklus II.

\section{b. Aktivitas Guru}

Data aktivitas guru setelah diperoleh proses belajar dengan menggunakan model pembelajaran example non example dan setiap siklus mengalami peningkatan. Data hasil aktivitas guru pada setiap siklus dapat dilihat pada gambar 2 dibawah ini: 


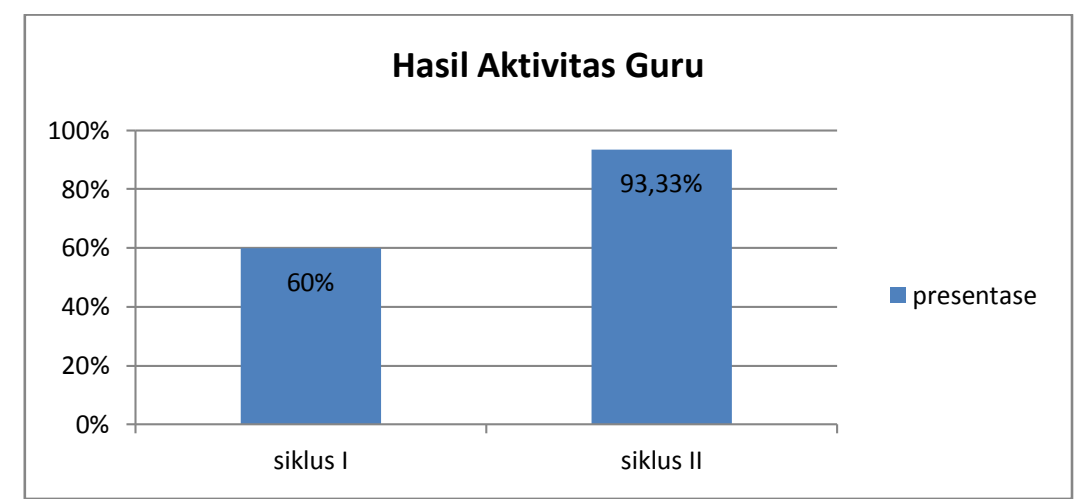

Gambar 2. Grafik Hasil Aktivitas Guru Pada Siklus I Dan Siklus II

Penerapan model pembelajaran example non example untuk meningkatkan hasil aktivitas belajar siswa yang dimana oleh observasi, pada saat proses belajar mengajar berlangsung aktivitas guru pada siklus I masih mengalami kekurangan dengan hasil perolehan skor 60\%. Hal ini disebabkan guru belum mampu menciptakan suasana pembelajaran yang lebih baik dan efektif atas penerapan model yang digunakan dan kurang memotivasi belajar siswa selama proses belajar mengajar berlangsung.

Tetapi pada siklus II mulai mengalami peningkatan dibandingkan pada pertemuan siklus I dengan skor perolehan $60 \%$ dan meningkat menjadi skor perolehan 93,33\% karena pada siklus II guru sudah mampu menciptakan suasana belajar yang menyenangkan dengan penyampaian materi yang lebih baik dan sudah memahami dan mengetahui bagaimana cara untuk menerapkan model pembelajaran example non example. Meningkatnya aktivitas dalam proses belajar mengajar didukung oleh meningkatnya aktivitas guru dalam memperbaiki dan meningkatnya suasana belajar. Guru intensif dalam membimbing siswa dan memberikan kejelasan materi sehingga siswa lebih antusias bertanya kepada guru dan menjawab pertanyaan dari guru.

\section{c. Hasil Belajar Siswa}

Pada awal pembelajaran peneliti menjelaskan strategi pembelajaran yang akan digunakan yaitu suatu strategi yang memberi kesempatan pada setiap siswa sebagai pengajar terhadap siswa lain dan peneliti juga menyampaikan tujuan pembelajaran yang yang ingin dicapai dapat diperoleh setelah melakukan peoses belajar mengajar didalam kelas dengan menggunakan strategi model pembelajaran Example Non Example.

Pada siklus I dilakukan II kali pertemuan dan pada pertemuan kedua ini setelah proses belajar mengajar selesai guru atau peneliti melakukan tes siklus I untuk mengetahui hasil belajar siswa dengan jumlah soal pilihan ganda sebanyak 15 soal kemudian siswa mengerjakan dan mengembalikan pada guri. Kemudian guru memeriksa hasil tes yang di peroleh tiap tiap siswa dan setelah dilihat hasilnya dari 36 siswa hanya 2 orang siswa yang mendapatkan nilai kkm yang tuntas dan 34 siswa lainya belum tuntas halin dapat kita lihat pada tabel 4.1 diatas dengan penerapan model pembelajaran example non example disekolah SMA negeri 10 kota ternate. Proses belajar mengajar pada siklus I belum berhasil dikarenakan siswa belum bisa memahami strategi pembelajaran yang dibawakan oleh peneliti, sehingga membuat siswa merasa bibngung halini dapat mempengaruhi hasil belajar siswa dengan skor perolehan 42 atau belum mencapai ketuntasan.

Hasil belajar siklus I dan siklus II meningkat setelah setelah pembelajaran dengan penerapan model pembelajaran exapmle non example untuk meningkatkan hasil belajara siswa. Hal ini terlihat pada grafik berikut ini. 
Eva Marthinu dan Rusdin Nurdin. 2019. hasil belajar, example non example, model pembelajaran, dinamika hidrosfer

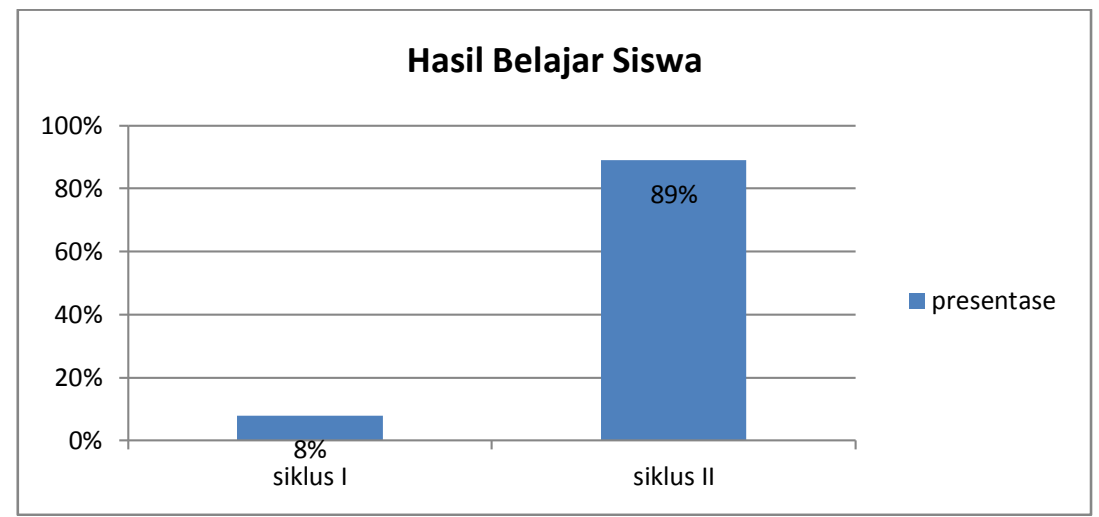

Gambar 3. Grafik Hasil Belajar Siswa Pada Siklus I Dan Siklus II

Pada siklus ini peneliti melakukam pertemuan dengan siswa sebanyak II dua kali tatap muka setelah proses belajar mengajar selesai peneliti membagikan lembar tes siklus II dengan jumlah soal 15 dalam bentuk pilihan ganda setelah siswa selesai mengisi lembaran tes siswa mengembalikanya ke pada peneliti data hasil belajar siswa diperoleh setelah peneliti memeriksa hasil tes yang dikerjakan siswa hasil yang diperoleh tiap siswa dilihat hasilnya dengan jumlah siswa sebanyak 36 siswa yang mengikuti tes dan yang tuntas sebanyak 32 siswa yang berhasil. Dari siklus II dengan skor perolehan $89 \%$. Hal ini dikarenakan peneliti sudah mampu menciptakan suasana belajar dikelas lebih baik dan siswa sudah terbiasa dengan metode yang digunakan oleh peneliti. Peneliti sudah mampu memberikan siswa dorongan dan motifasi agar lebih giat lagi mengikuti proses belajar mengajar dikelas atau aktif didalam setiap tahapan pembelajaran sehingga di siklus II hasil belajar siswa sudah mencapai ketuntasan KKM.

\section{KESIMPULAN}

Berdasarkan hasil penelitian yang telah dilakukan pada siswa kelas X SMA Negeri 10 Kota Ternate. Dapat disimpulkan beberapa kesimpulan bahwa aktifitas guru dalam penerapan model pembelajaran example non example guna meningkatkan hasil belajar siswa di SMA Negeri 10 Kota Ternate, Ketuntasan hasil belajar siswa secara keseluruhan dapat dilihat pada siklus I sebanyak 28 orang yang belum tuntas atau sebanyak $22 \%$ atau yang belum mencapai ketuntasan belajar KKM. Sedangkan pada siklus II sudah mengalami peningkatan hasil belajar siswa sebanyak 32 orang yang tuntas atau sebanyak 89\% siswa yang mencapai ketuntasan belajar, sehingga dapat dikatakan bahwa pada siklus II siswa dikatakan telah berhasil mencapai KKM.

\section{DAFTAR PUSTAKA}

Dalyono. 2007. Psikologi Pendidikan. Jakarta: Rineka Cipta.

Daryanto. (2010). Media Pembelajaran. Bandung: Satu Nusa.

Komalasari, Kokom. 2010. Pembelajaran Kontekstual. Bandung: Refika Aditama

Muslimin. Ibrahim. 2000. Model-Model Pembelajaran. Jakarta Rineka Cipta.

Nani I Rajaloa, Rustam Hasim "Manajemen Perencanaan dan Rekrutmen Tenaga Pendidik Oleh Dinas Pendidikan Kota Ternate " dalam EDUKASI - Jurnal Pendidikan, Vol. 16 No.1 Januari 2018.

Rochyandi. (2004). Model Mengajar \& Bahan Pembelajaran. (cetakan ke-2) Bandung: Alqaprint

Rustam Hasyim dan Subhan Hayun "Peranan Kepala Sekolah Sebagai Supervisior Dalam Meningkatkan Kualitas Pembelajaran (Telaah Teortik), DALAM Jurnal EDUKASI, Vol. 16No.2 Juni 2018.

Slameto. (1995).Belajar dan Faktor-faktor yang mempengaruhi,Jakarta, Rineka Cipta

Tohirin. (2006.) Psikologi pembelajaran agama islam. Jakarta: Raga Grafindo Perkasa 